
\title{
25 Research Suare \\ Cost-Benefit Analysis and Financial Viability of Household Biogas Plant Installation in Aleta Wondo District, Southern Ethiopia
}

\section{Tale Gedefa}

Oda Bultum University

\section{Yoseph Melka}

Wondo Genet College of Forestry and Natural Resources

Getachew Sime ( $\square$ abigiag@yahoo.com )

Department of Biology, College of Natural Sciences, Hawassa University, Hawassa, Ethiopia https://orcid.org/0000-0002-4406-3770

\section{Original article}

Keywords: Biogas energy, biogas plant size, cost-benefit analysis, Biomass energy, South Ethiopia

Posted Date: September 27th, 2021

DOl: https://doi.org/10.21203/rs.3.rs-910501/v1

License: (c) (i) This work is licensed under a Creative Commons Attribution 4.0 International License. Read Full License 


\section{Abstract}

Background: Installation of biogas plants has both costs and incomes; installation and maintenance service demand financial costs and reduction of costs for purchasing firewood, kerosene and chemical fertilizers are benefits or incomes. This study investigates the cost-benefit analysis and financial viability related to biogas plant installation in Southern Ethiopia.

Method: A multi-stage sampling technique was employed to select sample households. A total of 105 adopter households were selected for household survey.

Results and conclusion: The installation cost took the largest share of the total cost of installation and was one of the main constraints that hindered installation. Installation increased household income by reducing the costs incurred for buying firewood, kerosene and chemical fertilizers. Relatively, lower plant size was more profitable than larger plant size. Installation under the subsidy scheme was more financially viable at $10 \%$ discount rate than its counterparts. The profitability of lower plant size was more sensitive to changes in the discount rate, the level of expenditure saving and input price than larger plant size, under an assumption and without subsidy. Installation of low cost plants could more attract the engagement of a large number of rural households with low economic capacity. Besides, installation of lower plant sizes could more substantially enhance household income by saving costs incurred for buying firewood, kerosene and chemical fertilizers.

\section{Introduction}

The life of a human being is highly dependent on energy consumption (IEA, 2011). In daily lives, energy provides essential benefits for cooking, heating, lighting, food production and storage, industrial production, education, and transportation. In modern times, no country has managed to substantially reduce poverty without increasing energy resources and its efficient utilization (Rao et al., 2009). Energy consumption level is a good indicator of economic development level of a country because the energy sector has strong impact on poverty reduction through income and environment linkages (Sayin et al., 2005). Today, in African countries, reliance on and appliances of traditional biomass energy is a problem for sustainability of energy resource which leads to hold back economic development (Karekezi, 2002). For many Sub-Saharan Africa (SSA) countries, including Ethiopia, the energy demand and supply is continuously increasing as development progresses and population growth is faster increasing. However, modern domestic energy supply is disproportionate with its demand (Amigun et al., 2008). About $83 \%$ of the total population in SSA countries and $91 \%$ in less developed countries have no access to modern fuels (Legros et al., 2009). Likewise, Ethiopia is highly dependent on traditional biomass for domestic energy (for cooking, heating and lighting); more than $93 \%$ of its population obtains energy from biomass (WHO, 2006). Thus, the interest of having access to modern and renewable energy in Ethiopia has been increasing as the rural community is suffering from the energy crisis and ever increasing cost of chemical fertilizers (Mengistu et al., 2016) and kerosene (Sime et al., 2020). The use of chemical fertilizers becomes dominant and its volume is growing up annually with unaffordable prices (Mengistu et al., 
2016, Eshete et al., 2006). Similarly, the price of kerosene has also ever increasing (Sime et al., 2020). This situation could be improved by using biogas technology (Kamp and Forn, 2016). Furthermore, biomass fuel is becoming scarce and household productivity is being affected by the reallocation of time and labor from yield bearing activities the collection of biomass energy, which have led to reduced rural economy (Amare, 2014). Due to the ongoing deforestation and shortage of firewood, households need to look for other energy sources where a large number of people use residues from agriculture (straw, manure) instead. However, both straw and manure also have a function in agriculture for soil improvement (Bewket, 2012).

On the other hands, rural households in Ethiopia require about five to seven Giga Joule energy for cooking annually. Up to 4 ha of land or 15 cows are needed to provide enough straw and manure to cook on the traditional three stone fires. When more efficient techniques are used (briquetting, biogas) this can be reduced to 2 ha and 6 cows. This indicates that the use of improved energy conversion technology can help to save about $60 \%$ biomass. However, a large variation in resource availability exists between households. About $80 \%$ of the households owns less than 2 ha and $70 \%$ holds less than four cows. This means that, even when energy efficient techniques are used, the largest share of the population is not able to generate enough energy for cooking (Tucho and Nonhebel, 2015). The deployment of biogas energy as an alternative energy source can have the potential to fill the gap in the energy needs of the rural community if it is effectively managed and appropriately utilized (Kelebe et al., 2017). Biogas is an emerging bio-energy technology in the rural areas of Ethiopia through biogas development program for potential households (Gabisa and Gheewala, 2019).

As most of the rural households are involved in subsistence farming that integrates agriculture and animal husbandry. Thus, domestic biogas could theoretically not only foresee the need for cooking energy, but also provide a good source of organic fertilizer (Eshete et al., 2006). Therefore, biogas energy is appropriate technology for rural community of Ethiopia. It has multiple benefits such as the use of clean energy for cooking and lighting, the use of bio-slurry as organic fertilizer and income generation through reducing the use of purchasing fuels (firewood, charcoal and kerosene) and chemical fertilizers (Erdogdu, 2008, Bewket, 2012). Technical issues like the availability of feedstock (water and cow dung), and the existence of conducive temperature for operation of biogas make Ethiopia a country with abundant potential for biogas utilization (Eshete et al., 2006). In conformity, Ethiopia has launched its National Biogas Program (NBPE) in 2009, for dissemination of domestic biogas technology through a subsidy modality for at least one million households. Despite the numerous dissemination efforts, however, the economic potential of the technology has been largely remained indefinable and households are mostly seen to be doubtful to invest in it.

SNV - Ethiopia is supporting the implementation of this market-based domestic biogas programs in different countries in Asia and Africa with a view to establish a commercially viable biogas sector (Ghimire, 2013). Economic viability refers to an estimator that seeks to maximize the effectiveness of financial viability. Individual households judge profitability of biogas plants primarily from monetary surplus gained from utilizing biogas and bio-fertilizer in relation to the cost of the plants. Economic cost- 
benefit analysis is the most efficient and widely used tools for measuring whether any investment would be beneficial or not, along with their environmental and social concern (Chakrabarty et al., 2013, Gwavuya et al., 2012). Limited success in promoting improved energy sources, such as biogas, in rural areas of developing countries has been partly blamed on insufficient understanding of household energy use patterns (Gwavuya et al., 2012). In studying the cost-benefit analysis and financial viability of the biogas plant installation, incomes generated in terms of a monetary value encompass: expenditure saved due to the substitution of other energy sources with biogas, income generated from the sale of biogas (when applicable), replacing the cost of using chemical fertilizer by bio-slurry, income generated from the sale of bio-slurry (when applicable), time saved for collecting and preparing previously used fuel materials (when applicable), time saved for cooking after utilizing biogas energy (when this time can be used to generate income), improved indoor air quality and consequent reductions in medical expenditure for respiratory infections. This is because the biogas energy generated and bio-fertilizer produced can alleviate poverty by improving health conditions, increasing crop productivity and saving working time and reducing burden on women and children (Garfí et al., 2012). Similarly, the most important cost associated with biogas plant installation is manufacturing, acquisition costs (production costs), or capital costs. The production cost includes all expenses and incomes, which are necessary for the installation of biogas plants. It includes land, excavation work, cost of material for building biogas plant, gasholder and displacement pit (cement, bricks, blocks), gas stove, piping system, dung storage system, etc. Operation and maintenance costs mean running costs that include the cost of raw dung or foregone revenue from the sale of raw dung (Chakrabarty et al., 2013). Similarly, this study assumes that the installation of plants has both costs and incomes; installation and maintenance service demand financial costs, but reduces costs for purchasing firewood, kerosene and chemical fertilizers, which are regarded as benefits or incomes.

Installation of biogas plants for improving energy security and bio-slurry for increasing agricultural production are the two most important purposes behind domesticating biogas technology in rural Ethiopia. Besides that the technology is important for improving environmental health, reducing deforestation, and mitigating greenhouse gas emission. However, there are scanty studies dealing with the investigation of the cost-benefit analysis and financial viability related to the costs and incomes in biogas plant installation. This study is initiated to evaluate these perspectives of biogas technology in Sidama Region, Southern Ethiopia.

\section{Materials And Methods}

\section{Description of the study area}

Aleta Wondo district, the study area, is one of the 19 districts in the Sidama Region in southern Ethiopia. It is administratively divided into 27 rural Kebeles ${ }^{[1]}$, with the total of 32,309 households. It is located at 337 $\mathrm{km}$ to the south of Addis Ababa, the country's capital city and $62 \mathrm{~km}$ from Hawassa, the capital city of the regional state. It is located between $6^{0} 35^{\prime}$ and $6^{\circ} 40^{\prime} \mathrm{N}$ latitude, and between $38^{\circ} 23^{\prime}$ and $38^{\circ} 26^{\prime} \mathrm{E}$ 
longitude. According to the Central Statistical Agency (CSA) of Ethiopia, Aleta Wondo has a land area of $567.2 \mathrm{~km}^{2}$ with a population of 191,592 of whom 97,364 are males and 94,228 are females while 175,055 rural and 16,537 are urban population (CSA, 2013).

\section{Sampling design and sample size}

A multi-stage sampling technique was used for selecting sample households to be surveyed. First, the Aleta Wondo district was selected purposively for being the home of the largest number of biogas installations during the survey time. Secondly, only three kebeles were selected purposively from the 27 rural kebeles based on the availability of biogas plants as well as experience in biogas energy and bioslurry generation and utilization. The total number of installed biogas plants in the three kebeles was 103. The respective Kebele Executive Energy Offices provided the list of biogas adopter households. Thus, all adopters in the study kebeles were used as sampling units.

\section{Data sources and collections}

Primary data were collected through household questionnaire survey, key informant interviews, focus group discussion and field observations. Open ended and closed ended semi-structured questionnaire (for personal household interview) and checklists (for key informant interview, focus group discussion and field observation) were used for collecting quantitative and qualitative data. Researchers, and experienced and skilled data collectors together collected the data.

The questionnaire was administered to the 105 biogas adopter households. Three experienced and knowledgeable individuals were used as key informants in each Kebele. They were biogas adopters, Kebele Development Agents, and energy technicians. Twelve participants in each Kebele were used as focus group discussants. They were adopter households being grouped into men-headed and femaleheaded adopter households separately. The gender classification was to enable free discussion to avoid cultural influences of men over women. Each of the two groups had six members. Field observations were also carried out with both formal and informal discussants.

\section{Methods of data analysis}

\section{Data collected through survey}

The collected raw data were coded, edited and organized using a Microsoft Excel. Then, the organized data were entered and analyzed using STATA version 13.1 at $a=0.05$. The data were analyzed by using analytical methods such as descriptive statistics, inferential statistics, and economic analysis. The monetary benefits of household biogas plant was analyzed by paired-samples t-test. The cost of installation and maintenance service of biogas plants were analyzed using mean. Whereas data collected 
through key informant interviews, focus group discussion and field observations were transcribed and then broken into themes and subthemes.

\section{Estimation of costs and benefits}

The costs and benefits associated with biogas plants were quantified and estimated on the basis of valuation of kerosene, firewood, and chemical fertilizer consumptions. The cost of locally available material was valued at the local market price, while those of tradable components were valued at the local retail market prices. The annual maintenance cost was estimated as follows:

$M_{C}=0.04 C \ldots \ldots \ldots \ldots \ldots \ldots \ldots \ldots . . . . .1$

Where, $M_{C}$ is maintenance cost, $C$ is the total installation cost.

In this study, the monetary benefits of biogas plants were computed only for the saved costs on firewood and kerosene substituted by biogas energy and saved costs on chemical fertilizer substituted by the bioslurry. This is because there is no direct selling of biogas energy and bio-slurry in local markets. The time saved due to biogas energy use was not estimated owning to the fact that the time saved as a result of the redundant wood collection and cooking practices is categorized as an economic value (shadow prices) and is not monetary benefit (Lutz and Howarth, 2015).

The firewood consumptions per household were gathered in a unit of bundle per week, and later converted into kg per week and then into kg per year. It was, thus, estimated by the following the formula of Bala and Hossain (1992) as:

$\mathrm{TAB}_{\mathrm{f}}=52.143\left(\mathrm{WF}_{\mathrm{cb}}-\mathrm{WF}_{\mathrm{ca}}\right) \mathrm{P}_{\mathrm{fw}} \cdots \ldots \ldots \ldots . .2 .2$

Where, $\mathrm{TAB}_{\mathrm{f}}$ is the annual monetary benefits from firewood saving, 52.143 refers to 52.143 weeks per year, $\mathrm{WF}_{\mathrm{cb}}$ is the weekly firewood $(\mathrm{kg})$ consumption before adopting biogas technology, $\mathrm{WF}_{\mathrm{ca}}$ is the weekly firewood $(\mathrm{kg})$ consumption after biogas technology adoption per household and $\mathrm{P}_{\mathrm{fw}}$ is the price of firewood per $\mathrm{kg}$ at the time of collection.

Data related to kerosene consumption were considered in terms of number or a unit of bottle consumed per week and later was converted to litre (I). Consequently, the cost saved from kerosene consumption was calculated according to Bala and Hossain (1992):

$\mathrm{TAB}_{\mathrm{k}}=52.143\left(\mathrm{WK}_{\mathrm{cb}}-\mathrm{WK}_{\mathrm{ca}}\right) \mathrm{Pk} \ldots \ldots \ldots \ldots \ldots . .2 .3$

Where, $\mathrm{TAB}_{\mathrm{k}}$ is the annual monetary benefits from kerosene saving, 52.143 refers to 52.143 weeks per year, $\mathrm{WK}_{\mathrm{cb}}$, is the weekly kerosene consumption (I) before adopting biogas technology, $\mathrm{WK}_{\mathrm{ca}}$, is the weekly kerosene consumption (I) after adopting biogas technology per household and $P_{k}$ is the price of kerosene per I at the time of data collection. 
Following Biswas and Lucas (1997), the monetary benefit of bio-slurry was estimated using existing cost of chemical fertiliser consumption and was computed as follows:

$\mathrm{TAB}_{\mathrm{s}}=\left(\mathrm{ACh}_{\mathrm{b}}-\mathrm{ACh} \mathrm{h}_{\mathrm{a}}\right) \mathrm{p}_{\mathrm{ch} \cdots \cdots \cdots \cdots \cdots \ldots . .2 .4}$

Where, $T A B_{s}$ is the annual benefits from bio-slurry consumption, $A C h_{b}$ is the annual amount of chemical fertilizers consumption per household before adopting biogas technology, $\mathrm{ACh}_{\mathrm{a}}$ is annual amount of chemical fertilizers consumption per household after biogas adoption and $p_{c h}$, is the official price of chemical fertilizers (both DAP and Urea) at the time of data collection.

By combining the above formulae, the total annual monetary benefit of household biogas plants (TAB) was estimated as follows:

$\mathrm{TAB}=\mathrm{TAB}_{\mathrm{f}}+\mathrm{TAB}_{\mathrm{k}}+\mathrm{TAB} \mathrm{B}_{\mathrm{s}} \ldots \ldots \ldots \ldots \ldots . .2 .5$

Economic tools like Benefit Cost ratio (BCR), Pay Back Period (PBP) and Net Present Value (NPV) were employed for the economic analysis of the biogas plant installation and operation. A fixed dome biogas model (local name Sinidu, meaning "ready"), and $6 \mathrm{~m}^{3}$ and $8 \mathrm{~m}^{3}$ biogas plant sizes were selected for financial analysis. This is because they were the most commonly used model and size in the study area.

\section{Undiscounted Payback Period (UPBP)}

In this study, the annual net revenue was assumed to be constant. The UPBP was, therefore, used in the analysis because a constant rate is suitable for computations were annual benefits and maintenance costs are assumed uniformly over the useful economic life of a plant. Thus, the UPBP was calculated as follows:

$$
U P B P=\frac{C I}{A p} \ldots \ldots \ldots \ldots \ldots \ldots \ldots \ldots \ldots \ldots \ldots \ldots \ldots \ldots \ldots \ldots+2.6
$$

Where, $\mathrm{Cl}$ is total installation costs, AP is annual profit which is annual monetary benefits from biogas technology adoption.

\section{Net Present Value (NPV)}

According to Mmopelwa (2006), NPV is given by the following formula:

$$
\mathrm{NPV}=\sum_{\mathrm{t}=1}^{\mathrm{n}} \frac{\mathrm{B}_{\mathrm{t}}-\mathrm{C}_{\mathrm{t}}}{(1+\mathrm{r})^{\mathrm{t}}} \ldots \ldots \ldots \ldots \ldots . . . \ldots \ldots
$$


Where, $B_{t}$ is the benefit obtained from the biogas plant installation (biogas, bio-slurry) in each year, $C_{t}$ is the cost in each year, $t$ is the expected useful economic life of a fixed-dome biogas plant from the present; $t=(1,2 \ldots 15)$ and $r$ is the discount rate. $B_{t}$ and $C_{t}$ were assumed uniformly over the expected useful economic life of biogas plants and discounted across all year. A useful economic life of a fixed-dome plant was assumed to be 15 years. This was based on the quality of masons and materials used in the study area. A discount rate of $10 \%$ was assumed based on the recent minimum lending interest rate for long-term, which was provided by the Development Bank of Ethiopia (DBE) to farmers' association (MoFEC, 2016).

The internal rate of return (IRR) is the discount rate that makes the present value of future benefits. This is equal to the present value of any cost, which makes NPV equaling zero. The payback period is the period of time over which the accumulated cash flows will equal the initial outlay, i.e. payback period is the amount of time that takes for a project to recover its initial investment. A short payback period may be desirable to ensure that the capital expenditure is quickly recovered and repatriated so that at least the initial investment will have been recovered. An investment is profitable when its NPV is zero, the bigger NPV, the better the investment will be (von Braun, 2013, Sathe and Bhosale, 2013, Sinha and Kandpal, 1990).

\section{Benefits - Cost Ratio (BCR)}

The BCR is the ratio of benefits per unit of cost and was estimated (Rahman and Kholilullah, 2017):

$$
B C R=\frac{T B_{t} /(1+r)^{t}}{T C_{t} /(1+r)^{t}} \ldots \ldots \ldots \ldots R 8
$$

Where, $\mathrm{TB}_{\mathrm{t}}$ is the total financial benefits obtained from the biogas plant (biogas, bio-slurry), $\mathrm{TC}_{t}$ is the total costs (installation costs and annual maintenance costs) of biogas plant. $\mathrm{TB}_{\mathrm{t}}$ and $\mathrm{TC}_{\mathrm{t}}$ were discounted only at the initial year of investment $(t=1)$ because it is used to measure the present value of returns per money invested.

\section{Sensitivity analysis of selected variables}

Sensitivity analysis is required to identify those input variables that are important in terms of contributing to predict the output variation and in quantifying how changes in the values of input parameters alter the values of the output variable. Sensitivity of variables is often a non-linear, complex and unsteady process, so it is difficult to derive a linear formula to represent the influence of all variables in the process.

Furthermore, simplifying the nature of analysis using a linear model would lead to unreliable results in practical applications of this research. Therefore, the neural network is used as an alternative way of sensitivity analysis because it considers linearity and non-linearity. It is fast, accurate, viable and efficient 
alternative against the traditional techniques of sensitivity analysis (Costa et al., 2013, Dilidili et al., 2011).

In cost-benefit analysis, the result is always influenced by several uncertainties. Sensitivity analysis helps to know how sensitive the NPV is to change in those uncertain factors (key variables) (Díaz-Balteiro and Romero, 2004, Gwavuya et al., 2012). Therefore, sensitivity analysis was conducted to quantify the impact of change in key (selected) variables on the estimates of NPV to determine the financial stability of household biogas investment in the study area. In this study, the key variables were grouped into three sensitivity scenarios: input price scenario, the level of expenditure saving scenario (a saving of firewood, kerosene and chemical fertilizer) and discount rate scenario.

[1] "Kebele" is the smallest administrative unit in an Ethiopian Administrative Structure.

\section{Results And Discussion}

\section{Costs related to household biogas plant system}

The cost of household biogas system consisted of digester installation costs and operational costs (Table 1). The installation cost covers costs for purchasing the materials used for bio-digester construction, such as cement, bricks, sand, and PVC planks. The operational costs, whereas covers costs related to maintenance and other routine labour for feedstock preparation and feeding the biogas system. While operational costs are mostly related to costs incurred for maintenance service. In accordance, the total costs of the most commonly used fixed-dome household biogas plants of $6 \mathrm{~m}^{3}$ and $8 \mathrm{~m}^{3}$ biogas plant sizes were computed as total installation costs (Table 1) and maintenance costs (Table 2). The installation cost is expensive for most households. Hence, loans and subsidies are arranged. The survey data and secondary data obtained from Aleta Wondo District Water, Mine and Energy Office (AWDWMEO) (AWDWMEO, 2017) showed that all biogas owners acquire loans from the OMO Microfinance Institution (with a repayment period of 2 years and $15 \%$ interest rate). The loan was subsidized with the help of the National Biogas Programme of Ethiopia (NBPE). Since 2010, AWDWEMO has been endorsing a subsidy amounting ETB 6,000 for each household biogas plant regardless of plant sizes. Out of the subsidies, an amount amounting ETB 2,420 was the cost of supply line used for purchasing a biogas stove, biogas lamp with its accessory, valves (main gas, drainage and gas tap) and connectors, and electric wires. While the remaining ETB 3,580 was paid for biogas mason. The same subsidy was provided equally for all households and plant sizes. The payment for masons varied with plant sizes, ETB 1,300 for $6 \mathrm{~m}^{3}$ and ETB 1,600 for $8 \mathrm{~m}^{3}$. The rate had been uniform from 2010 to the time of the execution of this study. This payment would better change with time.

Table 1: Estimation of installation costs of household biogas plants 
Inputs (materials and labor) cost

Quantity of materials

and labor size required

for installation

$6 \mathrm{~m}^{3}$

$8 \mathrm{~m}^{3}$
Unit

price

(ETB)
Total cost of material and labor (ETB) required for

installation

$6 \mathrm{~m}^{3} \quad 8 \mathrm{~m}^{3}$

\section{A. Civil construction cost}

1.Cement (bags, $50 \mathrm{~kg}$ )

2. Sand (barrows)

3. PVC pipe $(6 \mathrm{~m}$ length and $70 \mathrm{~mm}$ diameter with its elbow)

4. Galvanized steel (dome gas pipe),

$1.5 \mathrm{~m}$ length and $60 \mathrm{~mm}$ diameter with its elbow

5. Iron bar ( $6 \mathrm{~m}$ length and $8 \mathrm{~mm}$ diameter with binds)

6. Transportation cost

Subtotal

B. Labor cost

1. Mason cost (paid by adopters)

2. Grave worker cost (barrows)

Subtotal

C. Total cost (A+B)

D. Subsidy

1. Cost of supply line

2. Mason (subsidized by NBPE)

Subtotal

F. Total installation cost (C+D)

$\begin{array}{lllll}11 & 16 & 135 & 1,485 & 2,160 \\ 12 & 18 & 75 & 900 & 1,350 \\ 2 & 4 & 150 & 300 & 600\end{array}$

$345 \quad 345 \quad 345$

7

11

165

1,155

1,815

210

240

4,395

6,510

Note: The average installation costs vary among households due to differences in plant size and costs of materials and labor required. All figures in the Table are rounded off to the nearest possible.

Table 2: Total installation and annual maintenance costs of biogas plants 


\section{Biogas plant size}

\begin{tabular}{llll}
\hline SN & Cost type & $\mathbf{6 ~ \mathbf { m } ^ { \mathbf { 3 } }}$ & $\mathbf{8} \mathbf{m}^{\mathbf{3}}$ \\
\hline 1. & Total installation cost (ETB) & 12,775 & 15,460 \\
\hline 2. & Annual maintenance cost (ETB) & 511 & 619 \\
\hline & Total cost (ETB) [1+2] & $\mathbf{1 3 , 2 8 6}$ & $\mathbf{1 6 , 0 7 9}$
\end{tabular}

As the plant size increased, the installation cost also increased proportionally. There was a proportional increase in cost between plant size and installation cost (Table 2). This is consistent with Lutz and Howarth (2015) that as the biogas plant size increases, so is the cost per $\mathrm{m}^{3}$ of plant. Though the cost of inputs is naturally increasing, the present installation cost is so much close to same cost calculated during the 2008 baseline survey of NBPE which was about ETB 13,000 for $6 \mathrm{~m}^{3}$ size (Eshete et al., 2006). The reason might be that installation depends on local construction materials and households hire no labour from outside. They use household members for executing labour related works, including excavation-work. Thus, the use of local material with no external costs and the lack of labour wages are the factors that have regulated inflation in installation costs over time.

\section{Monetary benefit from firewood consumption replacement with biogas system}

Depending on accessibility and choices, households' used a variety of energy sources. These energy sources were firewood, crop residues, kerosene and biogas energy. Firewood was utilized by the entire sample households for cooking. A few sample households still sell firewood while others purchase trees or logs for firewood. According to the Ministry of Agriculture (MoA) of Ethiopia, on average, one bundle of firewood weights $32 \mathrm{~kg}$ (MoA, 1996). On average, the selling price of one bundle of firewood in the area was about ETB 46.97 (at local retail market, January 27, 2017, when 1 USD=22.46, at the National Bank of Ethiopia (NBE)). Hence, the price of one $\mathrm{kg}$ firewood at the time of data collection was ETB 1.47.

The weekly average firewood consumption of adopter households before adoption was $103.53 \mathrm{~kg}$ per household $(\mathrm{HH})$ for $6 \mathrm{~m}^{3}$ and $107.29 \mathrm{~kg}$ per HH for $8 \mathrm{~m}^{3}$ plant sizes (Table 3). Whereas, it was $51.76 \mathrm{~kg}$ firewood per $\mathrm{HH}$ for $6 \mathrm{~m}^{3}$ and $52.39 \mathrm{~kg}$ firewood per $\mathrm{HH}$ for $8 \mathrm{~m}^{3}$ plant sizes, after adoption. As a result, households installing $6 \mathrm{~m}^{3}$ and $8 \mathrm{~m}^{3}$ were able to save 2,699.44 $\mathrm{kg}$ firewood per $\mathrm{HH}$ and 2,862.65 kg firewood per $\mathrm{HH}$, respectively, annually (Table 3). In terms of annual monetary benefit, the $6 \mathrm{~m}^{3}$ and 8 $\mathrm{m}^{3}$ helped the earning of respectively ETB 3,968.18 per HH and ETB 4208.09 per $\mathrm{HH}$, after adoption. Previous studies conducted in rural Ethiopia reported similar findings that adoption of biogas technology enables saving various sizes of firewood consumption and generates incomes (Gwavuya et al., 2012). The amount of firewood saved and income generated vary from localities to localities depending on the 
type of fuel available and choices, as well as the availability of markets and nature of market prices. For instance, biogas adopter households in the study area did not use charcoal and kerosene stove for cooking; they rather mostly use firewood for cooking.

\section{Monetary benefit from kerosene consumption replacement with biogas energy system}

In the study area, households use kerosene lamp for lighting purpose. Data on kerosene consumption was counted in a unit of bottle per week and was later converted to litre (I), 1 bottle » 0.33 I or 3 bottles » 1 I. The local retail market price of 1 litre of kerosene was ETB 27 (when 1 US\$=22.46, January 27, 2017). Adopter households had completely replaced kerosene consumption by biogas energy. Accordingly, they were able to save about 84.99 I kerosene with $6 \mathrm{~m}^{3}$ per $\mathrm{HH}$ and 89.69 I kerosene with $8 \mathrm{~m}^{3}$ per HH, annually (Table 4). Therefore, the use of $6 \mathrm{~m}^{3}$ and $8 \mathrm{~m}^{3}$ plants enabled generation of the annual income ETB 2,294.81 per HH and ETB 2,421.52 per HH, respectively. Results from a previous study conducted in rural Ethiopia reported similar findings that biogas energy soundly replace the use of kerosene and generates different amount of incomes (Mengistu et al., 2016). The amount of kerosene that can be replaced and income generated show spatial and temporal variations.

\section{Monetary benefit obtained from the cost saved from chemical fertilizers purchase}

The price of $100 \mathrm{~kg}$ of DAP and $100 \mathrm{~kg}$ of Urea was ETB 1,486 and ETB 1,374, respectively, at the time of data collection. The amount of bio-slurry generated from both plant sizes was found to be inadequate to cover all farmland. Thus, adopters were seen to still use DAP and Urea to cover farmlands that had not been covered with bio-slurry. Adoption enabled the saving of $154.90 \mathrm{~kg}$ per HH per year and $162.26 \mathrm{~kg}$ per $\mathrm{HH}$ per year of DAP consumption from $6 \mathrm{~m}^{3}$ and $8 \mathrm{~m}^{3}$ plants, respectively (Table 5 ). Accordingly, the annual monetary benefit when DAP was substituted with bio-slurry was ETB 2,301.81 per HH from $6 \mathrm{~m}^{3}$ and ETB 2,411.18 per $\mathrm{HH}$ from $8 \mathrm{~m}^{3}$ plants (Table 5). In this regard, adopter households DAP consumption before and after adoption of both plant sizes were significantly different $(p<0.01)$. The amount of urea saved by adopter households was $85.78 \mathrm{~kg}$ per HH per year for $6 \mathrm{~m}^{3}$ and $94.60 \mathrm{~kg}$ per HH per year for $8 \mathrm{~m}^{3}$ plants (Table 5). Accordingly, the annual monetary benefit adopters obtained from the cost spent on urea when substituted with bio-slurry was ETB 1,178.62 per $\mathrm{HH}$ and 1,299.80 per $\mathrm{HH} 6 \mathrm{~m}^{3}$ and $8 \mathrm{~m}^{3}$ plants, respectively. Similar findings were reported (Amare, 2014) that adoption of biogas technology enables substitution of chemical fertilizers and generation of incomes. The amount of substitutions made and monetary benefits generated appear to depend on multiple factors, such as the amount of bio-slurry generated and its effective use as a quality source of bio-fertilizer, the price and type of the replaced chemical fertilizers, sizes farmland owned by adopter households and level of households' awareness. In addition to the energy aspects of biogas technology, the bio-slurry aspect of 
the technology need sound attention and promotion strategies. For successful biogas program in Ethiopia, both aspects of the technology, bio-gas energy and bio-slurry, should be promoted as an integral strategy of ensuring rural energy and food security. The technology's major outputs are ideal in augmenting the prevailingly practiced mixed crop-livestock farming system in rural Ethiopia.

Table 3: Weekly firewood consumption before and after biogas plant installation

\begin{tabular}{|c|c|c|c|c|c|c|c|}
\hline Variable & $\begin{array}{l}\text { Plant } \\
\text { size }\end{array}$ & Category & Minimum & Maximum & Mean \pm SD & $\begin{array}{l}\mathrm{t}- \\
\text { value }\end{array}$ & p-value \\
\hline \multirow{4}{*}{$\begin{array}{l}\text { Firewood } \\
(\mathrm{Kg})\end{array}$} & \multirow[t]{2}{*}{$6 \mathrm{~m}^{3}$} & $\begin{array}{l}\text { Before } \\
\text { adoption }\end{array}$ & 64 & 128 & $103.53 \pm 37.50$ & & \\
\hline & & $\begin{array}{l}\text { After } \\
\text { adoption }\end{array}$ & 32 & 64 & $51.76 \pm 15.21$ & 9.135 & $0.000^{\star \star \star}$ \\
\hline & \multirow[t]{2}{*}{$8 \mathrm{~m}^{3}$} & $\begin{array}{l}\text { Before } \\
\text { adoption }\end{array}$ & 96 & 128 & $107.29 \pm 36.53$ & & \\
\hline & & $\begin{array}{l}\text { After } \\
\text { adoption }\end{array}$ & 32 & 64 & $52.39 \pm 15.04$ & 9.926 & $0.000^{\star \star \star}$ \\
\hline
\end{tabular}

Note: ${ }^{* \star *}$ represents $1 \%$ level of significance

Table 4: Weekly kerosene consumption before and after biogas plant installation

\begin{tabular}{llllllll} 
Variable & $\begin{array}{l}\text { Plant } \\
\text { size }\end{array}$ & Category & Minimum & Maximum & $\begin{array}{l}\text { Mean } \pm \\
\text { SD }\end{array}$ & t-value & p-value \\
\hline Kerosene $(\mathrm{L})$ & $6 \mathrm{~m}^{3}$ & $\begin{array}{l}\text { Before } \\
\text { adoption }\end{array}$ & 0.67 & 2.00 & $1.63 \pm 0.68$ & & \\
\hline & & $\begin{array}{l}\text { After } \\
\text { adoption }\end{array}$ & 0.00 & 0.00 & $0.00 \pm 0.00$ & 17.202 & $0.000 \star \star \star$ \\
\hline $8 \mathrm{~m}^{3}$ & $\begin{array}{l}\text { Before } \\
\text { adoption }\end{array}$ & 1.00 & 2.33 & $1.72 \pm 0.67$ & & \\
\hline & $\begin{array}{l}\text { After } \\
\text { adoption }\end{array}$ & 0.00 & 0.00 & $0.00 \pm 0.00$ & 18.443 & $0.000 \star \star \star$ \\
\hline
\end{tabular}

Note: ${ }^{* * *}$ represents $1 \%$ level of significance

Table 5: Annual chemical fertilizers consumption before and after biogas plant installation 


\begin{tabular}{|c|c|c|c|c|c|c|c|}
\hline & $\begin{array}{l}\text { Plant } \\
\text { Size }\end{array}$ & Category & Minimum & Maximum & Mean \pm SD & t-value & p-value \\
\hline \multirow[t]{4}{*}{$\begin{array}{l}\text { DAP } \\
\text { used }(\mathrm{kg})\end{array}$} & $6 \mathrm{~m}^{3}$ & $\begin{array}{l}\text { Before } \\
\text { adoption }\end{array}$ & 75 & 250 & $179.41 \pm 58.80$ & & \\
\hline & & $\begin{array}{l}\text { After } \\
\text { adoption }\end{array}$ & 0.00 & 100 & $24.51 \pm 40.15$ & 15.521 & $0.000^{\star \star \star}$ \\
\hline & $8 \mathrm{~m}^{3}$ & $\begin{array}{l}\text { Before } \\
\text { adoption }\end{array}$ & 100 & 275 & $188.24 \pm 57.52$ & & \\
\hline & & $\begin{array}{l}\text { After } \\
\text { adoption }\end{array}$ & 0.00 & 125 & $25.98 \pm 29.14$ & 16.668 & $0.000^{\star \star \star}$ \\
\hline \multirow[t]{4}{*}{$\begin{array}{l}\text { Urea } \\
\text { used (kg) }\end{array}$} & $6 \mathrm{~m}^{3}$ & $\begin{array}{l}\text { Before } \\
\text { adoption }\end{array}$ & 50 & 50 & $104.41 \pm 45.75$ & & \\
\hline & & $\begin{array}{l}\text { After } \\
\text { adoption }\end{array}$ & 0.00 & 150 & $18.63 \pm 17.92$ & 12.469 & $0.000^{\star \star \star}$ \\
\hline & $8 \mathrm{~m}^{3}$ & $\begin{array}{l}\text { Before } \\
\text { adoption }\end{array}$ & 75 & 175 & $115.19 \pm 45.02$ & & \\
\hline & & $\begin{array}{l}\text { After } \\
\text { adoption }\end{array}$ & 0.00 & 75 & $20.59 \pm 19.82$ & 13.735 & $0.000^{\star \star \star}$ \\
\hline
\end{tabular}

Note: ${ }^{* * *}$ represents $1 \%$ level of significance

Table 6: Summary of annual monetary benefits from household biogas plant installation

Variable

Biogas plant

size

$6 m^{3} \quad 8 m^{3}$

\section{A. Annual monetary benefit from biogas energy (ETB)}

1. Monetary benefit from replacing firewood consumption with biogas energy (ETB)

2. Monetary benefit from replacing kerosene consumption with biogas energy (ETB)

B. Annual monetary benefit from bio-slurry (ETB)

1. Monetary benefit from saving cost for buying chemical fertilizer, DAP (ETB) $\quad 2,302 \quad 2,411$

2. Monetary benefit from saving cost for buying chemical fertilizer, urea (ETB) $\quad 1,179 \quad 1,299$

Total annual monetary benefit from biogas plant installation (ETB) $[A+B] \quad 9,744 \quad 10,341$ 


\section{Financial viability of household biogas plants}

The financial estimation in this study considers only the costs and monetary benefits of the biogas investment, not including some other external costs and benefits. The survey result showed that all installed biogas plants were subsidized. For this reason, the financial viability of households' investment into biogas plant installation was evaluated as with a subsidy (base assumption) and without a subsidy. Under without subsidy situation, no external financial incentive was incorporated into the calculation of a biogas plant. Without subsidy estimation of a biogas plant offered the actual cost to be incurred for installation of a biogas plant. Such an arrangement seems to attract interested households in investing in biogas installation. Particularly, households, who for financial limitation, could not adopt will be potential beneficiaries of subsidies. While with the subsidy estimation of a biogas plants provided that a subsidy plays vital role in increasing the adoption rate and in attracting low income households to biogas technology adoption. Hence, for the financial estimation of a biogas plant installation with a subsidy, the finance allocated (ETB 6000) was subtracted from the calculated cost of installation for each biogas plant.

\section{Undiscounted Payback Period (UPBP)}

Biogas plant with subsidy in both sizes repaid the original cost of investment in a shorter period than biogas plant without subsidy. Investing in $6 \mathrm{~m}^{3}$ biogas plants with subsidy recovered the installation cost within 0.73 years, while the $8 \mathrm{~m}^{3}$ plants recovered the installation cost within 0.97 years (Table 7). This implies that a household with a $6 \mathrm{~m}^{3}$ plants would take a few months to recover the original cost of investment through the annual net cash revenues it generates than the $8 \mathrm{~m}^{3}$ plants.

Under the assumption of without subsidy, the payback period of $6 \mathrm{~m}^{3}$ biogas plant was shorter than 8 $\mathrm{m}^{3}$ biogas plants (Table 7). However, both plants take a long period when compared with a subsidized scheme to recover the initial investment costs, which was 1.38 years for $6 \mathrm{~m}^{3}$ and 1.59 years for 8 $\mathrm{m}^{3}$ biogas plants. Therefore, considering subsidy arrangement to biogas adopters, based on the UPBP results, the $6 \mathrm{~m}^{3}$ plant with a shorter period was more financially viable than the $8 \mathrm{~m}^{3}$ plants. This implies that as the size of the biogas plant increases, the UPBP also increases. The $8 \mathrm{~m}^{3}$ biogas plants had higher installation costs than the $6 \mathrm{~m}^{3}$ plants.

Table 7: The results of UPBP with and without subsidy of biogas plants

\section{Payback period (years)}

\begin{tabular}{llll}
\hline SN & Undiscounted & $\mathbf{6 \mathrm { m } ^ { 3 }}$ & $\mathbf{8 \mathrm { m } ^ { 3 }}$ \\
\hline 1 & With subsidy & 0.73 & 0.97 \\
\hline 2 & Without subsidy & 1.38 & 1.59 \\
\hline
\end{tabular}




\section{Net Present Value (NPV)}

The NPV is a way of comparing the present and future values of cash flow by using discount rate and a time constraint. Under both assumptions, the NPV results for $6 \mathrm{~m}^{3}$ and $8 \mathrm{~m}^{3}$ biogas plant sizes were turned out to be positive (Table 8). Positive NPV means that the biogas investment is preferable, and profitable for further investment. It means that the cost invested for the respective plant size was smaller than the income generated. The NPV for $6 \mathrm{~m}^{3}$ biogas plant was ETB 56508 and ETB 55674 for 8 $\mathrm{m}^{3}$ under the assumption with subsidy while the NPV under the assumption without subsidy was ETB 51053 for $6 \mathrm{~m}^{3}$ biogas plants and ETB 50219 for $8 \mathrm{~m}^{3}$ plants (Table 8). This implies that a $6 \mathrm{~m}^{3}$ biogas plant; under both assumptions with and without subsidy, would be more sensitive to changes in financial parameters and profitable than the $8 \mathrm{~m}^{3}$ size. The biogas investment without subsidy in both $6 \mathrm{~m}^{3}$ and 8 $\mathrm{m}^{3}$ plants are less viable than of biogas investment with a subsidy (Table 8 ). Such economic performance of biogas plants is an important factor for households who consider biogas plants as an investment.

Table 8: The results of NPV with subsidy and without subsidy of biogas plants

\section{Net Present Value(ETB)}

\begin{tabular}{llll}
\hline $\mathbf{S N}$ & Scenario & $\mathbf{6} \mathbf{m}^{\mathbf{3}}$ & $\mathbf{8 \mathbf { m } ^ { \mathbf { 3 } }}$ \\
\hline 1 & With subsidy & 56508 & 55674 \\
\hline 2 & Without subsidy & 51053 & 50219
\end{tabular}

This result is in line with Gwavuya et al. (2012) that small size biogas plants in Ethiopia were more profitable than large size plants. Kabir et al. (2012) showed that under the assumption with subsidy, biogas users in Bangladesh obtain better financial results compared to assumption without subsidy. However, under both assumptions biogas investment yields positive NPVs. Households largely collect their own fuel. Nevertheless, by investing in biogas plants, they could save time and energy, and have a supply of bio-slurry that can be used as fertilizer in agricultural production. A cost-benefit analysis of biogas plants yields positive NPVs for households collecting their own energy sources. Even higher NPVs are obtained for households purchasing all of their energy needs. These households stand to gain significantly from the financial benefits of energy cost savings with biogas technology adoption. These financial benefits are highly dependent on bio-slurry being effectively used as a source of fertilizer, with the price of the replaced chemical fertilizers and fuel sources as well as saving costs related receiving health services. These financial benefits hold under the assumption of subsidies that biogas plants are highly subsidized under the existing scheme. 


\section{Benefit - Cost Ratio (BCR)}

The BCR was used to measure the present value of returns per ETB invested. The financial analysis of $B C R$, under the assumption with subsidy, was found to be 1.34 and 1.10 at $10 \%$ discount rate of $6 \mathrm{~m}^{3}$ and $8 \mathrm{~m}^{3}$ plants, respectively (Table 9). This means that the investment in biogas plant by ETB 1.0 would provide a return (profit) of 34 cents for $6 \mathrm{~m}^{3}$ and 10 cents for $8 \mathrm{~m}^{3}$ plants. Therefore, the use of biogas plant was more viable as the cost associated with it is outweighed by the benefit obtained. The results of BCR also showed $6 \mathrm{~m}^{3}$ biogas plant was more financially profitable than $8 \mathrm{~m}^{3}$ plants. Biogas investment was more financially profitable under the assumption with subsidy for both biogas plant sizes, while it was unprofitable under the assumption without subsidy in the initial year (Table 9).

Table 9: The results of BCR with subsidy and without subsidy of biogas plants

\section{Benefit - Cost Ratio (BCR)}

\begin{tabular}{llll}
\hline SN & Scenario & $\mathbf{6 ~ \mathbf { m } ^ { 3 }}$ & $\mathbf{8 ~ \mathbf { m } ^ { 3 }}$ \\
\hline 1 & With subsidy & 1.34 & 1.10 \\
\hline 2 & Without subsidy & 0.74 & 0.64
\end{tabular}

The effect of the biogas subsidy on NPV was analyzed and respective trends were found. Accordingly, break-is reached during the seventh year for households purchasing firewood. For households collecting firewood and dung, however, break-even is reached during the 18th and 14th year, respectively, without subsidy. The greatest effect of subsidy is realized for households collecting firewood. Without subsidy, households collecting firewood and adopting a larger biogas plant sizes realize positive NPV value in relatively shorter years than smaller sizes.

\section{Sensitivity analysis}

Sensitivity analysis results of the NPV of biogas investment were presented (Table 10). Sensitivity analysis was conducted in three scenarios: input price scenario, the level of expenditure saving scenario and discount rate scenario. The base case, which is a standard for this study, was used as reference for comparison of changes in NPV of biogas plants. For the level of expenditure saving scenario, the minimum (for decreasing), average (for base case) and maximum (for increasing) values of expenditure saving were used as input data. Based on these data, the level of expenditure saving was assumed on average $10 \%$, decreasing and $10 \%$ increasing from the base case. The input price scenario was taken based on market price assessment of the local market, the past price (for decreasing), current (for base case) and foreseeable future price (for increasing) values. Thus, the input price scenario was assumed as $10 \%$, decreasing and $20 \%$ increasing prices. Based on the researchers' logical basis of market price changes in demand and supply for money, the discount rate scenario was assumed $10 \%$ for the decrease discount rate and $20 \%$ for increase discount rates from the base case (the standard for the study is 10 
\%). Sensitivity analysis was then conducted to determine changes in cost of biogas investment as price of construction materials and maintenance cost, which could be sensitive to change. Sensitivity analysis was also conducted to determine changes to household benefit accumulation under different conditions. These conditions include level of expenditure saving firewood, kerosene and chemical fertilizer. The level of expenditure saving may change household consumption patterns. Similarly, as the level of saving changes the monetary benefit that would generate from biogas plant changes. For households collecting dung and for households collecting firewood, the shadow price and market price of replacing fuel increase soundly. This signals the importance of opportunity cost of labour in determining the anticipated benefits of investing in biogas plants. Thus, well-off households stand to benefit more than poorer households. Change in the benefits accruing with a larger plant size is higher for increases in shadow price of replacing fuel compared with smaller plant size. It was, however, lower when it comes to the level of expenditure and time saving. Besides, sensitivity to change is higher for households collecting firewood and dung compared to households purchasing firewood.

The NPV for the $6 \mathrm{~m}^{3}$ plant was highly sensitive to input prices, the level of expenditure savings and discount rates than that of $8 \mathrm{~m}^{3}$ plant across three scenarios, which could give the discounted return at the shorter time period (Table 10). A similar result was reported that compared to larger sizes, the NPV for smaller plant type was highly sensitive to time savings, construction costs, expenditure levels and the price of replacing fuel across household scenarios. These variables are under the household status sensitivity scenario and indicate the importance of household variables, especially for households collecting firewood and dung (Gwavuya et al., 2012). Likewise, as these key variables would be changed, the NPVs also changed, assuming the other variables remain constant such as economic life of biogas plant. The same is true; the magnitude of NPV in both plant sizes and assumptions (with and without subsidy) would change. Therefore, the best scenario NPV occurs when the level of expenditure savings increases while the input prices and discount rates decrease. The worse NPV scenario occurs when input prices and discount rate increase, and the level of expenditure savings decreases. This result is supported by Verdone (2015) that discounting is making events at different points in time that long economic life of the projects is sensitive to the of discount rates. Therefore, the choice of an appropriate discount rate is highly important to ensure future project returns. As input prices and level of expenditure change, the sensitivity of NPVs value increases (Gwavuya et al., 2012).

Table 10: Sensitivity analysis of biogas plant investment for changes in key variables 


\begin{tabular}{|c|c|c|c|c|}
\hline \multirow[b]{2}{*}{ Variables } & \multicolumn{4}{|c|}{ NPV values change as key variables change } \\
\hline & $\begin{array}{l}\text { Plant } \\
\text { size }\end{array}$ & $\begin{array}{l}\text { Discount rate } \\
(9 \%)\end{array}$ & $\begin{array}{l}\text { Discount rate } \\
(10 \%)\end{array}$ & $\begin{array}{l}\text { Discount rate } \\
(12 \%)\end{array}$ \\
\hline \multirow[t]{2}{*}{ Base case } & $6 \mathrm{~m}^{3}$ & $60767(55263)$ & $56508(51053)$ & 49088(43731) \\
\hline & $8 \mathrm{~m}^{3}$ & $59738(54233)$ & $55674(50219)$ & $48591(43252)$ \\
\hline \multirow[t]{2}{*}{ Increase in price } & $6 \mathrm{~m}^{3}$ & 31113(18462) & 27648(16406) & $247570(1469)$ \\
\hline & $8 m^{3}$ & 45425(1902) & 40365(1795) & $36145(1607)$ \\
\hline \multirow[t]{2}{*}{ Decrease in price } & $6 \mathrm{~m}^{3}$ & 20085(28946) & 22430(32325) & 23770(34257) \\
\hline & $8 m^{3}$ & $55525(2531)$ & $49340(2388)$ & $44182(2139)$ \\
\hline \multirow{2}{*}{$\begin{array}{l}\text { Increase in level of expenditure } \\
\text { savings }\end{array}$} & $6 \mathrm{~m}^{3}$ & 49089(43732) & $56509(51055)$ & $60768(55264)$ \\
\hline & $8 \mathrm{~m}^{3}$ & $48634(44152$ & $55743(51318)$ & $59739(54236)$ \\
\hline \multirow{2}{*}{$\begin{array}{l}\text { Decrease in level of expenditure } \\
\text { savings }\end{array}$} & $6 \mathrm{~m}^{3}$ & $59667(54261)$ & $55512(51641)$ & $48189(49732)$ \\
\hline & $8 \mathrm{~m}^{3}$ & $58538(55333)$ & $56673(50719)$ & $50991(44651)$ \\
\hline
\end{tabular}

Note: Figures in the parentheses represent NPV values without subsidy.

\section{Application of biogas plants in the Kebeles}

The use of biogas plants played a substantial role in the reduction of the amount of firewood, kerosene and chemical fertilizers consumptions of households. Specifically, the biogas energy helped adopters by providing an alternative source of energy through substituting the use of traditional fuels for cooking and lighting and kerosene for lighting while the use of bio-slurry substituted the use of chemical fertilizers. In doing so, the use of the plants increased household income, reduced deforestation, abridged women's drudgery and avoided indoor air pollution. The adopter households were satisfied with the installation of the biogas plants despite that there were constraints, including shortage of spare parts, inadequate maintenance services, lack of stove for baking local bread and high initial invest cost.

\section{Conclusion And Recommendations}

This study specifically focuses on the fixed dome model of biogas plant sizes of $6 \mathrm{~m}^{3}$ and $8 \mathrm{~m}^{3}$ and estimated their cost-benefit analysis and financial viability at household level. Although biogas technology has continued to be adopted by households through incentives, its financial viability was 
undisclosed to the rural households in the study area. The total costs of biogas investment were ETB 13,286 and ETB 16,079 for $6 \mathrm{~m}^{3}$ and $8 \mathrm{~m}^{3}$ plant sizes, respectively. The respective benefits obtained from the two sizes were ETB 9,744 and ETB 10,341, showing that the costs are higher than the benefits. Likewise, the corresponding installation costs were ETB 12,775 and ETB 15,460. Proportionately, the installation cost was the leading investment cost that primarily hindered the successful dissemination of biogas technology. Adoption of biogas technology not only substantially reduces the consumption of firewood, kerosene and chemical fertilizer, but also markedly enhances household's income by saving their purchasing expenses. The financial analysis of both plant sizes, installed with subsidy, had higher NPV value, UPBP of less than one year and a BCR value of greater than one. This indicates that investing in both plant sizes is financially viable and profitable at $10 \%$ discount rate. Nevertheless, both plant sizes, installed without subsidy, had smaller NPV values and UDBP values greater than one year, making this scenario financially less viable. Distinctly, the $6 \mathrm{~m}^{3}$ size is highly profitable than the $8 \mathrm{~m}^{3}$ size. This implies that subsidy is important to enhance biogas plant installation, particularly in larger sizes. Moreover, sensitivity analysis showed that the profitability of biogas investment, expressed in NPV, is highly sensitive to variation in discount rates, level of expenditure savings and input prices. Households estimate the profitability of biogas plant installation primarily from monetary surplus gained from utilizing biogas energy and bio-slurry in association with the cost of the plants. Households are often motivated by subsidy and loan, which attract the engagement of low-income households in biogas plant installation. Furthermore, household's investment in biogas plant installation is more financially viable under the assumption with subsidy than without subsidy. Therefore, for the successful dissemination of the biogas technology and further popularization, the operating subsidy scheme, being offered by the NBPE and SNV-Ethiopia, should continue at least for a certain period and until the biogas benefits are effectively familiarized among rural households.

\section{Declarations}

\section{Acknowledgments}

We would like to thank NORHED - EnPe, a collaborative project between Hawassa University, Mekelle University and Norwegian University of Life Sciences (NMBU), for providing financial support. We owe due appreciation to all respondent households, group discussants and key informants who provided invaluable information. We also offer due respect to all organizations and their staff for providing invaluable data. Particularly, we would like to thank the following organizations: South Region Biogas Programme coordination Unit, Aleta Wondo District Energy and Mines Office, Aleta Wondo District Agriculture and Rural Development Office, Aleta Wondo District Administration Office, and Kebele Administrations.

\section{Authors' contributions}

Both authors designed the research and conducted primary data collection and analysis for the studies. In addition, both authors edited and approved the final manuscript. 


\section{Funding}

This research was funded by a Research and Capacity Building in Clean and Renewable Bioenergy in Ethiopia (NMBU - Hawassa - Mekelle), NMBU Project \# 3207010021, an institutional collaboration project between the Norwegian University of Life Sciences (NMBU), Norway, and Hawassa and Mekelle Universities, Ethiopia.

\section{Availability of data and materials}

Not applicable.

\section{Competing interests}

The authors declare that they have no competing interests.

\section{Ethics approval and consent to participate}

Not applicable

\section{Consent for publication}

We, authors, allow the publisher to publish our work

\section{Competing interests}

The authors declare no competing interests

\section{References}

1. AMARE, Z. Y. 2014. The role of Biogas Energy Production and Use in Greenhouse Gas Emission Reduction; the case of Amhara National Regional State, Fogera District, Ethiopia. benefits, 1.

2. AMIGUN, B., SIGAMONEY, R. \& VON BLOTTNITZ, H. 2008. Commercialisation of biofuel industry in Africa: a review. Renewable and sustainable energy reviews, 12, 690-711.

3. AWDWMEO 2017. Aleta Wondo District Water, Mine and Energy Office (AWDWMEO), Aleta Wondo, Southern Ethiopia.

4. BALA, B. \& HOSSAIN, M. 1992. Economics of biogas digesters in Bangladesh. Energy, 17, 939-944.

5. BEWKET, W. 2012. Climate change perceptions and adaptive responses of smallholder farmers in central highlands of Ethiopia. International Journal of environmental studies, 69, 507-523.

6. BISWAS, W. K. \& LUCAS, N. 1997. Economic viability of biogas technology in a Bangladesh village. Energy, 22, 763-770.

7. CHAKRABARTY, S., BOKSH, F. M. \& CHAKRABORTY, A. 2013. Economic viability of biogas and green self-employment opportunities. Renewable and Sustainable Energy Reviews, 28, 757-766. 
8. COSTA, S. P., DE ANDRADE LIMA, F. R., LAPA, C. M. F., DE ABREU MÓL, A. C. \& DE OLIVEIRA LIRA, C. A. B. 2013. The artificial neural network used in the study of sensitivities in the IRIS reactor pressurizer. Progress in Nuclear Energy, 69, 64-70.

9. CSA 2013. Population Projection of Ethiopia for all regions at district level (2014-2017). Central Statistics Agency (CSA), Addis Ababa, Ethiopia.

10. DíAZ-BALTEIRO, L. \& ROMERO, C. 2004. In search of a natural systems sustainability index. Ecological Economics, 49, 401-405.

11. DILIDILI, J., POLINGA, C., ARARAO-PELLE, R. \& SANGALANG, R. 2011. Biogas technology in Philippines: A synthesis of various readings on biogas technology. Cavite.

12. ERDOGDU, E. 2008. An expose of bioenergy and its potential and utilization in Turkey. Energy Policy, $36,2182-2190$.

13. ESHETE, G., SONDER, K. \& TER HEEGDE, F. 2006. Report on the feasibility study of a national programme for domestic biogas in Ethiopia. SNV Netherlands Development Organization: Addis Ababa, Ethiopia.

14. GABISA, E. W. \& GHEEWALA, S. H. 2019. Potential, environmental, and socio-economic assessment of biogas production in Ethiopia: The case of Amhara regional state. Biomass and Bioenergy, 122, 446-456.

15. GARFÍ, M., FERRER-MARTí, L., VELO, E. \& FERRER, I. 2012. Evaluating benefits of low-cost household digesters for rural Andean communities. Renewable and Sustainable Energy Reviews, 16, 575-581.

16. GHIMIRE, P. C. 2013. SNV supported domestic biogas programmes in Asia and Africa. Renewable Energy, 49, 90-94.

17. GWAVUYA, S., ABELE, S., BARFUSS, I., ZELLER, M. \& MÜLLER, J. 2012. Household energy economics in rural Ethiopia: A cost-benefit analysis of biogas energy. Renewable Energy, 48, 202-209.

18. IEA 2011. “World Energy Model - Methodology And Assumptions”, International Energy Agency, Paris Cedex, France.

19. KABIR, H., PALASH, M. \& BAUER, S. 2012. Appraisal of domestic biogas plants in Bangladesh. Bangladesh Journal of Agricultural Economics, 35, 71.

20. KAMP, L. M. \& FORN, E. B. 2016. Ethiopia! s emerging domestic biogas sector: Current status, bottlenecks and drivers. Renewable and Sustainable Energy Reviews, 60, 475-488.

21. KAREKEZI, S. 2002. Renewables in Africa-meeting the energy needs of the poor. Energy Policy, 30, 1059-1069.

22. KELEBE, H. E., AYIMUT, K. M., BERHE, G. H. \& HINTSA, K. 2017. Determinants for adoption decision of small scale biogas technology by rural households in Tigray, Ethiopia. Energy Economics, 66, 272278.

23. LEGROS, G., HAVET, I., BRUCE, N., BONJOUR, S., RIJAL, K. \& TAKADA, M. 2009. The energy access situation in developing countries: a review focusing on the least developed countries and SubSaharan Africa. World Health Organization and UNDP. 
24. LUTZ, D. A. \& HOWARTH, R. B. 2015. The price of snow: albedo valuation and a case study for forest management. Environmental Research Letters, 10, 064013.

25. MENGISTU, M. G., SIMANE, B., ESHETE, G. \& WORKNEH, T. S. 2016. Factors affecting households' decisions in biogas technology adoption, the case of Ofla and Mecha Districts, northern Ethiopia. Renewable Energy, 93, 215-227.

26. MMOPELWA, G. 2006. Economic and financial analysis of harvesting and utilization of river reed in the Okavango Delta, Botswana. Journal of environmental management, 79, 329-335.

27. MOA 1996. Woody Biomass Inventory for Strategic Planning. Biomass Conversion Factors for Some Selected Units of Measurement, Ministry of Agriculture (MoA), Addis Ababa, Ethiopia.

28. MOFEC 2016. Ministry of Finance and Economic Cooperation of the Federal Democratic Republic of Ethiopia (MoFEC): International Development Association Project Appraisal Document on a Proposed Credit in the amount of SD 144.8 Million, Addis Ababa, Ethiopia.

29. RAHMAN, M. A. \& KHOLILULLAH, M. I. 2017. Use of Solar Panel at Rural Areas in Bangladesh: Impacts, Financial Viability and Future Prospects. International Journal of Science and Research (IJSR), 6, 398-404.

30. RAO, P. S. C., MILLER, J. B., WANG, Y. D. \& BYRNE, J. B. 2009. Energy-microfinance intervention for below poverty line households in India. Energy Policy, 37, 1694-1712.

31. SATHE, S. S. \& BHOSALE, L. J. 2013. Socio-economic aspects of mangroves: potential of biogas production. Nature Environment and Pollution Technology, 12, 147.

32. SAYIN, C., MENCET, M. N. \& OZKAN, B. 2005. Assessing of energy policies based on Turkish agriculture:: current status and some implications. Energy Policy, 33, 2361-2373.

33. SIME, G., TILAHUN, G. \& KEBEDE, M. 2020. Assessment of biomass energy use pattern and biogas technology domestication programme in Ethiopia. African Journal of Science, Technology, Innovation and Development, 1-11.

34. SINHA, C. S. \& KANDPAL, T. C. 1990. A framework for the financial evaluation of household biogas plants in India. Biomass, 23, 39-53.

35. TUCHO, G. \& NONHEBEL, S. 2015. Bio-wastes as an alternative household cooking energy source in Ethiopia. Energies, 8, 9565-9583.

36. VERDONE, M. 2015. A cost-benefit framework for analyzing forest landscape restoration decisions. IUCN (International Union for Conservation of Nature), Gland, Switzerland.

37. VON BRAUN, J. Bioeconomy-science and technology policy for agricultural development and food security. Festschrift seminar in honor of Per Pinstrup-Andersen on "New directions in the fight against hunger and malnutrition". Cornell University, 2013.

38. WHO 2006. UNAIDS: Air quality guidelines: global update 2005, World Health Organization.

\section{Figures}




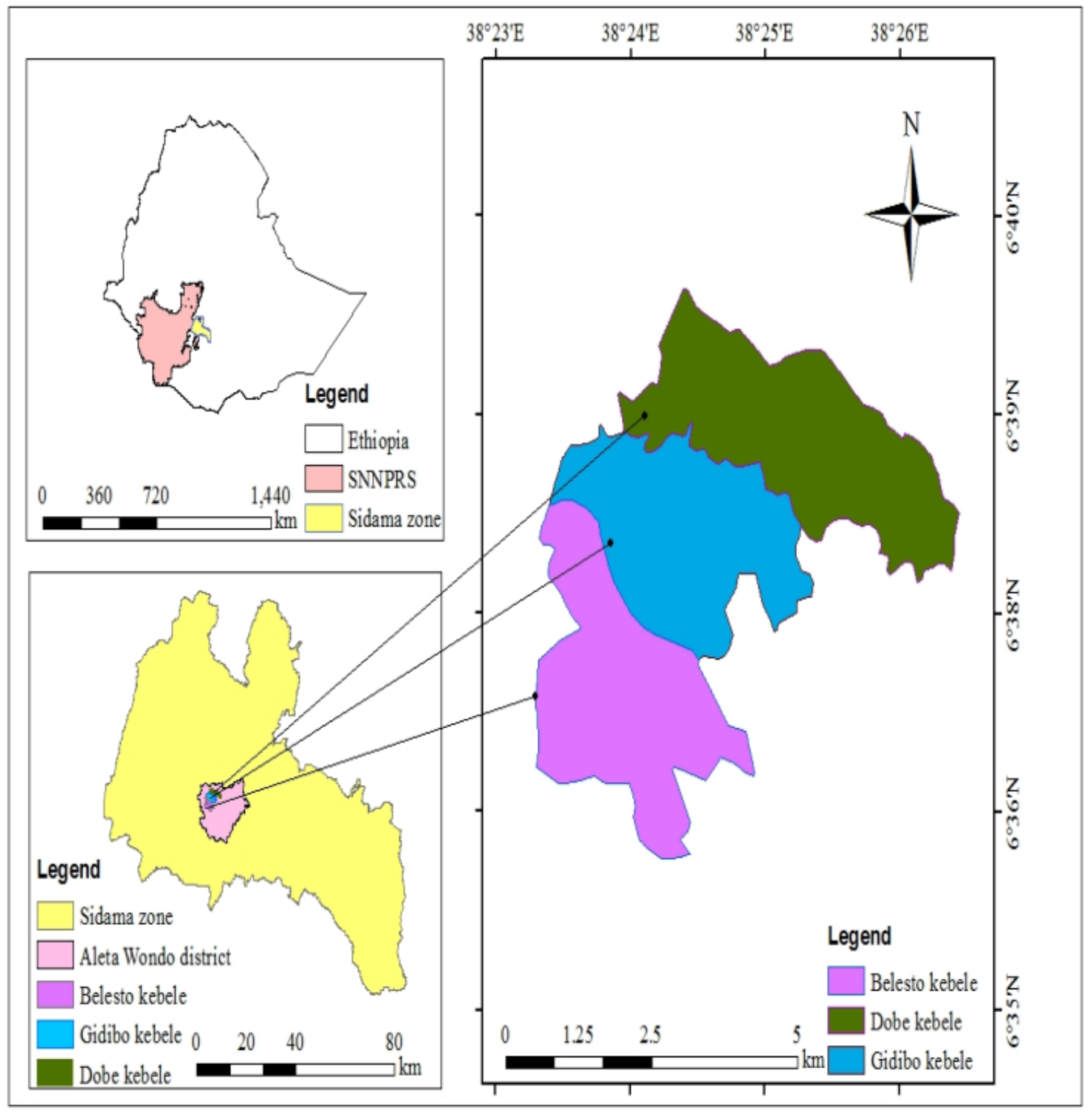

Figure 1

Physical map of the study area 